\title{
ЦЕЛЕНАПРАВЛЕННЫЙ СИНТЕЗ АЗОМЕТИНОВ 2-АМИНО-ТЕТРАГИДРО-БЕНЗОТИОФЕН-З-КАРБОКСАМИДА, ВЛИЯЮЩИХ НА ЦОГ-2
}

\section{А.С. Чиряпкин ${ }^{1}$, И.П. Кодониди', А.В. Ивченко', Л.П. Смирнова',}

М.В. Ларский

${ }^{1}$ Кафедра органической химии, Пятигорский медико-фармацевтический институт - филиал ФГБОУ ВО «ВолгГМУ» Министерства здравоохранения Российской Федерации, 357532, Россия, г. Пятигорск, пр. Калинина, д. 11.

${ }^{2}$ Кафедра фармацевтической химии, Пятигорский медико-фармацевтический институт - филиал ФГБОУ ВО «ВолгГМУ» Министерства здравоохранения Российской Федерации, 357532, Россия, г. Пятигорск, пр. Калинина, д. 11.

DOI: 10.19163/MedChemRussia2021-2021-524

E-mail: alexey.chiriapkin@yandex.ru

Предварительный прогноз противовоспалительной активности осуществлялся посредством молекулярного докинга с использованием трехмерной структуры ЦОГ-2 из базы данных RCSB Protein Data Bank (rcsb.org) с идентификационным номером 2IKT [1] в программе Autodock 4.0 [2]. Изучено образование 14 комплексов моделируемых азометинов с активным сайтом ЦОГ-2. Данные докинга свидетельствуют о высоком сродстве к белковой мишени азометиновых производных 2-амино-4,5,6,7-тетрагидро-1-бензотиофен-3-карбоксамида в случае наличия в ароматических заместителях атомов галогенов. Далее осуществлен синтез наиболее перспективных соединений, который проводили путем взаимодействия 4,5,6,7-тетрагидро-1-бензотиофен-3-карбоксамида с ароматическими альдегидами в среде этанола при кипячении в течение 30-60 минут. Данные ЯМР спектроскопии подтвердили структуры полученных азометинов. На рисунке показано расположение соединения-лидера $\mathrm{c} \mathrm{R}=2-\mathrm{OH}-3-\mathrm{OCH}_{3}-5-\mathrm{Br}$ в активном сайте ЦОГ-2 по результатам молекулярного докинга.
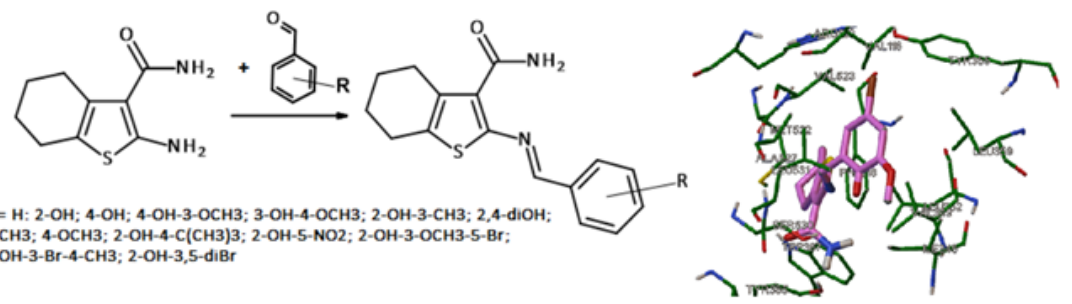

Исследование выполнено при финансовой поддержке РФФИ в рамках научного проекта № 20-315-90060.

\section{Литература}

[1] Orlando, B.J, Malkowski, M.G., JBiolChem. 2016, 291:15069-15081.

[2] Morris G.M., Huey R., Lindstrom W., Sanner M.F., Belew R.K., Goodsell D.S., Olson A.J. Journal of Computational Chemistry.2009, 30(16):2785-2791. 